\title{
ANALIZA WDRAŻANIA INSTRUMENTÓW WSPARCIA JAKOŚCI KREDYTOWEJ WSPÓŁFINANSOWANYCH ZE ŚRODKÓW EUROPEJSKICH W LATACH 2007-2013 NA PODSTAWIE UDZIELONEJ POMOCY DE MINIMIS
}

\begin{abstract}
Streszczenie
Zgodnie z założeniami umowy partnerstwa, w okresie programowania 2014-2020 nastąi zwiększenie wykorzystania instrumentów zwrotnych, w tym instrumentów poręczeniowych. Docelowa wartość portfela poręczeniowo-gwarancyjnego w przyszłym okresie programowania może przekroczyć nawet 10 mld PLN. Konieczne jest więc podejmowanie analiz efektywności zastosowanych instrumentów poręczeniowych współfinansowanych ze środków europejskich, w szczególności w perspektywie 2007-2013. Bazując na danych dotyczących pomocy de minimis udzielonej w ramach systemów poręczeniowych, przeprowadzono m.in. analizę tempa wdrażania i korzyści dla MŚP wynikajacych z udzielonych gwarancji. Zaprezentowane wyniki odniesiono do zmian prawnych oraz innych wydarzeń mogących mieć wpływ na analizowane zmienne.
\end{abstract}

Słowa kluczowe: gwarancje kredytowe, fundusze unijne, pomoc publiczna

\section{ANALYSIS OF IMPLEMENTATION GUARANTEES CO-FINANCED IN EUROPEAN FUNDS IN 2007-2013, ON THE BASIS OF STATE AID}

\section{Summary}

In accordance with the assumptions underlying the Partnership Agreement, in the programming period 2014-2020 there will be an increased use of refundable instruments, including credit guarantee instruments. The target value of the credit guarantee portfolio in the future programming period may exceed as much as PLN 10 billion. Thus it is necessary to perform efficiency analyses of the applied credit guarantee instruments co-financed with EU funds, in particular within the Financial Framework 2007-2013. Relying on the data relating to the de minimis support granted within the guarantee systems, an analysis has been performed on the implementation time and benefits of the provided guarantees for SMEs. The presented results were referred to legal changes and other events that may affect the analysed variables.

Key words: credit guarantees, EU funds, state aid

${ }^{1}$ Dr Marcin Wajda - Katedra Skarbowości, Szkoła Główna Handlowa w Warszawie; e-mail: marcin. wajda@sgh.waw.pl. 


\section{Wstęp}

Jedna z form zmniejszenia przez banki ekspozycji na ryzyko jest stosowanie zabezpieczeń. Jest to szczególnie ważne wśród klientów detalicznych oraz mikro, małych i średnich przedsiębiorstw (MŚP), którzy w odróżnieniu dla dużych korporacyjnych klientów nie mają odpowiednich wskaźników finansowych, które moga potwierdzać ich zdolność kredytowa. Do instrumentów mogących poprawić jakość kredytową pozycji sekurytyzowanych w polskim systemie prawnym można zaliczyć m.in. poręczenia. Zostały one uregulowane na gruncie Tytułu XXXII Kodeksu Cymilnego, w myśl którego poręczenie jest pisemną: umowa, w której porecryyciel zobowiazuje sie wagledem wierayciela wykonać zobowiazania na mypadek, gdyby dtuinnik, zobowiqzania nie wykonat (art. 876 Kodeksu Cywilnego). Ze względu na łatwa możliwość lewarowania środków, instrument ten został również zastosowany do dystrybucji środków europejskich w perspektywie finansowej Unii Europejskiej 2007-2013. Jest on wykorzystywany zarówno w formie przekazywania w zarządzanie kapitału (najczęściej funduszom poręczeniowym) w celu udzielania poręczeń indywidualnych, jak i w formie reporęczeń dla funduszy poręczeniowych oraz $\mathrm{w}$ formie poręczeń portfelowych wdrażanych m.in. bezpośrednio przez banki.

$\mathrm{Na}$ świecie istnieje kilkadziesiąt różnych modeli gwarancyjnych (poza Polską nie istnieją systemy poręczeniowe, całość jest rozumiana jako credit guarantee) różniących się od siebie m.in.: strukturą własności (publiczne, prywatne, mieszane), systemem finansowania (publicznym, prywatnym, mieszanym), rola państwa (aktywna, pasywna), zakresem działania (np. dokonującego oceny kredytowej bądź też nie) itp. Głównym celem funkcjonowania każdego systemu gwarancyjnego jest transfer i rozproszenie ryzyka. Transfer ten w przypadku wykorzystania funduszy poręczeniowych odbywa się z systemu regulowanego do systemu nieregulowanego. Zarządzanie ryzykiem w systemie nieregulowanym - choć w polskich warunkach słabo rozwinięte - odbywa się poprzez reporęczenia oferowane w ramach Inicjatywy JEREMIE oraz Programu na rzecz Konkurencyjności i Innowacji (CIP)

\section{Instrumenty gwarancyjne w perspektywie finansowej 2007-2013}

Wykorzystanie instrumentów gwarancyjnych w realizacji programów unijnych jest spowodowane m.in. możliwością lewarowania środków. Z uwagi na występowanie ryzyka hazardu moralnego, na rynku nie występuja poręczenia większe niż 80\% kwalifikowalnej wartości pożyczki albo kredytów. Jak pokazują wyniki badań przeglądowych, poręczenia kształtują się w przedziale $60-80 \%$ wartości zobowiązania [Analiza stanu..., 2014, s. 5]. Prowadząc akcję poręczeniowa, fundusz nie musi więc zakładać ryzyka pełnej straty na portfelu. Jeżeli cieszy się on zaufaniem sektora finansowego, to może dokonać nadkontraktacji i tym samym w prosty sposób doprowadzić do lewarowania środków. Innym mechanizmem stosowanym w ramach Inicjatywy JEREMIE jest CAP, który określa maksymalny poziom wypłat dla poręczanego portfela. 
Kolejnym powodem wykorzystania poręczeń jest ich niewielki, negatywny wpływ na gospodarkę w stosunku do innych instrumentów. Należy podkreślić, iż każdej interwencji publicznej może towarzyszyć zawodność państwa. Zawodność ta objawia się m.in. w efekcie wypychania środków prywatnych przez środki publiczne lub aktywnego poszukiwania renty. W przypadku dystrybucji instrumentów dłużnych rząd (rozumiany jako władza centralna lub samorządowa) może sparametryzować i wdrażać produkty bez współpracy z sektorem prywatnym albo wykorzystując go wyłącznie jako pośrednika. Instrument wsparcia jakości kredytowej, ze względu na fakt, iż nie obejmuje całości zobowiązania oraz sam nie jest źródłem finansowania, a jedynie ułatwia do niego dostęp, wymusza kooperację celów publicznych i prywatnych. Wobec tego, że głównymi odbiorcami poręczeń są banki (także one są źródłem finansowania), ewentualna strata netto powstała w wyniku zaburzenia mechanizmów rynkowych jest zminimalizowana.

Instrumenty poręczeniowe, współfinansowane w perspektywie 2007-2013 ze środków europejskich, są wdrażane w Regionalnych Programach Operacyjnych (RPO) oraz w Programie Operacyjnym Rozwój Polski Wschodniej (PO RPW). Zgodnie z zagregowanymi danymi Ministerstwa Infrastruktury i Rozwoju, wartość umów podpisanych z ostatecznymi odbiorcami w ramach RPO to 1236 mln PLN [Stan wdrażania..., 2014], natomiast w ramach PO RPW to $36 \mathrm{mln}$ PLN [Stan realizacji PO RPW..., 2014]. Istnieja dwa podstawowe modele wdrażania instrumentów finansowych w perspektywie finansowej 2007-2013. Pierwszy, zwany Inicjatywa JEREMIE, zakłada istnienie funduszu powierniczego, który jest zarządzany przez wybranego menadżera. Menadżer, działając w porozumieniu z odpowiednią instytucją zarządzająca (zarządem województwa), od której otrzymuje w zarządzanie środki, wybiera pośredników finansowych i określa alokację na poszczególne produkty. W ramach tego modelu są wdrażane m.in. poręczenia portfelowe i reporęczenia. Drugi z modeli zakłada wdrażanie instrumentów bez udziału menadżera. W tym przypadku odpowiednia instytucja zarządzająca jawnie decyduje o pośredniku, który otrzymuje w zarządzanie środki. W Polsce w okresie 2007-2013 Inicjatywa JEREMIE jest wdrażana w siedmiu województwach. Poza Kujawsko-Pomorskim Funduszem Pożyczkowym, rolę menadżera pełni również Bank Gospodarstwa Krajowego. W pozostałych województwach jest wdrażany model bezpośredni lub mieszany.

\section{Pomoc publiczna w prawie europejskim i polskim}

Pojęcie pomocy publicznej zostało określone w Unii Europejskiej. Zgodnie z art. 107 Traktatu o Funkcjonowaniu Unii Europejskiej (TFUE): z zastrzęzeniem innych postanowien przewidzrianych w Traktatach, wszelka pomoc prayznawana przez Panstwo Cztonkowskie lub priy usycin zasobów panstwonych w jakiejkolwiek. formie, która zaktóca lub grozi zaktóceniem konkurencii popržz sprazyjanie niektórym pržedsiębiorstwom lub produkciji niektórych towarón, jest niezgodna z. yynkiem wewnetrznym w zakresie, w jakim wplywa na wymiane handlowa miedzy Państwami Cz̨łonkowskimi. W powyższej definicji warto zwrócić uwage na dwa elementy. Po pierwsze, jest to określenie, że źródłem pomocy jest państwo rozumiane jako władza (na 
każdym szczeblu) wykorzystujące swoje zasoby zarówno bezpośrednio, jak i pośrednio. Po drugie, pomoc musi zakłócać lub grozić zakłóceniem konkurencji. Otrzymanie więc gwarancji ze środków publicznych po cenie niższej niż rynkowej, niezależnie przez kogo jest dystrybuowana, jest pomoca publiczną ${ }^{2}$.

W ramach pomocy publicznej wyróżnia się pomoc de minimis. Zgodnie ze stanem prawnym obowiązującym w okresie od 2007 do 2013 roku, pomoc de minimis zakłada między innymi, że przyznanie jednemu przedsiębiorcy w okresie trzech lat kwoty pomocy w wysokości 200 tys. EUR (albo 100 tys. EUR w przypadku sektora drogowego transportu towarów) nie jest niezgodna z art. 107 TFUE. W Polsce kwestia pomocy publicznej, w tym pomocy de minimis, w odniesieniu do RPO została uregulowana w Rozporzadzeniu Ministra Rozwoju Regionalnego z. dnia 26 października 2011 roku w sprawie udzielania pomocy ze środków inżynierii finansowej w ramach regionalnych programów operacyjnych (Dz. U. Nr 245, poz. 1461), natomiast w odniesieniu do PO RPW jest to Rozporzqdzenie Ministra Rozwoju Regionalnego z dnia 13 września 2011 roku w sprawie udzielania przez Polska Agencje Rozwoju Przedsiębiorczości pomocy finansowej na rozwój instrumentów inżynierii finansowej w ramach Programu Operacyjnego Rozwój Polski Wschodniej 2007-2013 (Dz. U. 2011, Nr 210, poz. 1255). W przypadku tego pierwszego dokumentu zostało określone, że rozporzadzenia nie stosuje się (a więc nie jest pomoca publiczną i pomocą de minimis) do: poręczenia splaty kredytu lub innego zobowiazania finansowego udzielanego prz̨edsiebiorcy (...), jeżeli:

a) pray udzielaniu poręczenia stosuje sie stawke bezpieczna, o której mowa w pkt 3.3. obwieszczenia Komisji w sprawie zastosowania art. 87 i 88 Traktatu WE do pomocy państwa w formie gwarancij (Dz. Ur₹. UE C 155 ₹ 20.06.2008, s. 10), lub stawke wyżsqq.

W celu uznania rynkowego charakteru poręczenia np. posiadania przez przedsiębiorcę ratingu, przywołany dokument wymaga jednej z trzech dużych agencji ratingowych, a dodatkowo proponowane stawki są zdecydowanie wyższe niż dotychczas dostępne na polskim rynku (np. dla start-upów stawka to 3,8\%). To powoduje, iż udzielanie poręczeń bez pomocy publicznej jest w Polsce nieatrakcyjne.

Gdy nie ma możliwości ustalenia wartości rynkowej poręczenia lub gwarancji, wielkość pomocy publicznej zgodnie z Rozporzqdzeniem Rady Ministrów z dnia 11 sierpnia 2004 roku w sprawie sžczególowego sposobu obliczania wartości pomocy publicznej udzielanej w różnych formach jest obliczana jako: różnica między zdyskontowana wartościq odsetek od pożyczki, kredytu lub innego zobowiqzania usyskanego na warunkach rynkowych bezporeczenia lub gwarancji a zdyskontowanq wartościq odsetek od pożyczki, kredytu lub innego zobowiazania uzyskanego drieki udzieleniu poreczenia lub gwarancji, pomniejszonq o wartość oplaty prowizyjnej zapłaconej za udzielenie poreczenia lub gwarancji; gdy ustalenie rynkowej stopy procentowej napotyka znaczne trudności, wartość odsetek odpowiadajaca warunkom rynkowym ustala sie pray zastosowaniu stopy referencyjnej (art. 4 ust. 8 lit. B).

${ }^{2}$ Warto podkreślić, iż pomoc publiczna może występować na różnych poziomach. O ile oczywiste jest jej występowanie na poziomie ostatecznego odbiorcy, o tyle dyskusyjne, ale jednak możliwe, jest występowanie również pomocy na drugim poziomie, to znaczy w przypadku korzyści dla banku z wprowadzenia gwarancji portfelowej. W przedmiotowej pracy pomoc na poziomie pośrednika nie będzie analizowana. 


\section{Analiza udzielonej pomocy publicznej $w$ instrumentach poręczeniowych}

Analizując dane związane z udzieloną pomoca publiczna, warto na wstępie odnieść się do danych dotyczących koncentracji środków na poręczenia. Według stanu na koniec II kwartału 2013 roku wyłącznie w stosunku do RPO i instrumentów wdrażanych bez udziału menadżera funduszu powierniczego, pięć największych funduszy poręczeniowych otrzymało około $50 \%$ wszystkich środków, natomiast dziesięć największych ponad $70 \%$. Powyższe pokazuje, iż dystrybucja instrumentów gwarancyjnych w ramach rozmaitych programów operacyjnych znacząco różni się. Największy z pośredników Małopolski Regionalny Fundusz Poręczeniowy sp. z o.o. otrzymał na udzielanie gwarancji kwotę 53 mln PLN, zaś najmniejszy Towarzystwo Rozwoju Gminy Płużnica kwotę 1,1 mln PLN [Informacja kwartalna..., 2013].

TABELA 1.

Wskaźnik koncentracji funduszy poręczeniowych

\begin{tabular}{|c|c|c|}
\hline Wskaźnik koncentracji & Kwota & \% do całości \\
\hline 5 & 246859349 & $49 \%$ \\
10 & 365150020 & $73 \%$ \\
15 & 420031693 & $84 \%$ \\
20 & 463938999 & $93 \%$ \\
\hline
\end{tabular}

Źródło: opracowanie własne na podstawie danych MIR (MRR), [Informacja kwartalna nt. stanu realizacii instrumentón zwrotnych $w$ ramach NSRO..., 2013].

Pierwsze środki przeznaczone na instrumenty gwarancyjne, wdrażane bez funkcji menadżera funduszu powierniczego, były uruchomiane od III kwartału 2009 roku. Jak ilustruje to wykres 1., przekazywanie w zarządzanie środków trwało w zasadzie do końca 2010 roku. W 2012 roku przekazano do funduszy poręczeniowych ostatnie $15 \mathrm{mln}$ PLN. Niezależnie od tego, w wybranych województwach pośrednicy mieli również możliwość skorzystania ze środków dostępnych w ramach Inicjatywy JEREMIE.

Zgodnie z danymi Urzędu Ochrony Konkurencji i Konsumentów (stan na koniec 2013 roku), najwięcej poręczeń i gwarancji w Polsce udzielono w latach 2007-2013 na podstawie Ustany z dnia 8 maja 1997 roku o poreczeniach i gwarancjach udrielanych przez Skarb Państwa oraz niektóre osoby prawne (Dz. U. 1997, Nr 79, poz. 484). Powyższe wynika z uruchomiania rządowego programu gwarancji de minimis, w ramach którego do końca 2013 roku udzielono 7 mld PLN gwarancji [Informacja BGK...]. Druga podstawa prawna, posiadająca istotny wkład $\mathrm{w}$ obszarze poręczeń i gwarancji z pomocą de minimis, była Ustawa z. dnia 6 grudnia 2006 roku o zasadach prowadzenia polityki rozwoju (Dz. U. 2006, $\mathrm{Nr} 227$, poz. 1658), która jest podstawą wdrażania wszystkich programów operacyjnych w perspektywie 2007-2013. Pozostałe podstawy prawne, nawet zsumowane, nie stanowia istotnej części udzielania gwarancji de minimis $\mathrm{w}$ ramach produktów wsparcia jakości kredytowej. 
WYKRES 1. Tempo przekazywania środków do pośredników finansowych w ramach instrumentów poręczeniowych (dane dla instrumentów wdrażanych bez udziału menadżera funduszu powierniczego, stan na koniec II kwartału 2013 roku)

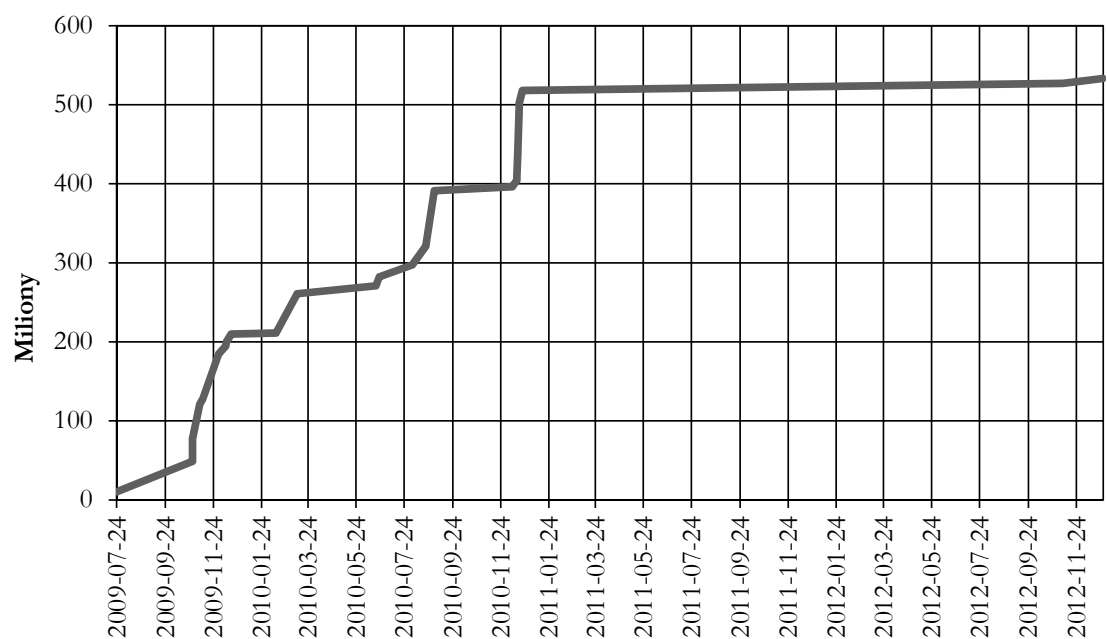

Źródło: opracowanie własne na podstawie danych MIR (MRR), [Informacja kwartalna nt. stanu realizacii instrumentów zwrotnych $w$ ramach NSRO..., 2013].

TABELA 2.

Pomoc de minimis w latach 2007-2013 w ramach instrumentów gwarancyjnych i poręczeniowych

\begin{tabular}{|l|l|}
\hline \multicolumn{1}{|c|}{ Podstawa prawna } & \multicolumn{1}{|c|}{ Suma (PLN) } \\
\hline Ustawa z dnia 8 maja 1997 roku o poreczeniach i gwarancjach udzielanych & 7001709 443,54 \\
przez Skarb Panstwa oraz niektóre osoby prawne & \\
Ustawa z dnia 6 grudnia 2006 roku o zasadach prowadzenia polityki roz- & 1118914971,01 \\
woju & 42475 644,42 \\
Inne ustawy & $\mathbf{8 1 6 3 1 0 0 ~ 0 5 8 , 9 7}$ \\
\hline Suma końcowa &
\end{tabular}

Źródło: opracowanie własne na podstawie danych UOKiK.

Przechodząc do analizy średniej wartości poręczenia w danym kwartale, można zauważyć występowanie wysokiej fluktuacji w trzech pierwszych początkowych okresach, kiedy zagregowana wartość udzielonych poręczeń była niewielka. Szczytowym okresem ze względu na zagregowaną wartość poręczeń w danym kwartale, jak i średnia wartość poręczenia w kwartale był II kwartał 2012 roku. Warto zwrócić uwagę, iż w całym badanym okresie średnia wartość udzielanych poręczeń zwiększyła się z 80 do około 120 tys. PLN. 
WYKRES 2. Średnia wartość poręczenia i wartość udzielonych poręczeń w danym kwartale

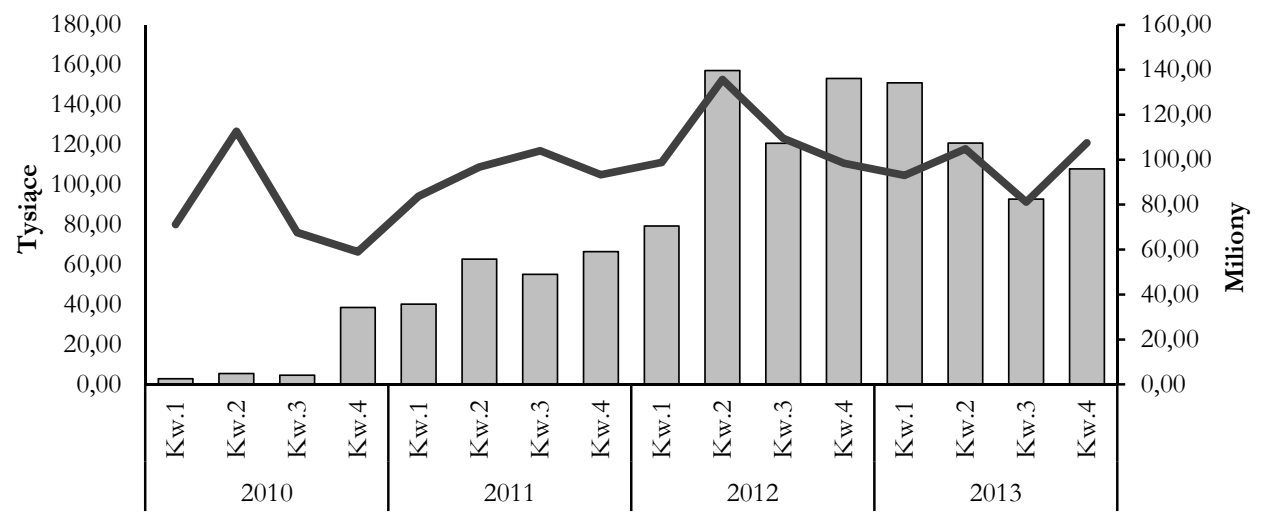

$\square$ Suma kwartalna kwoty nominalnej pomocy (prawa oś)

Średnia kwartalna kwoty nominalnej pomocy (lewa oś)

Źródło: opracowanie własne na podstawie danych UOKiK.

Jak wskazuje to wykres 1., na instrumenty gwarancyjne do III kwartału 2010 roku przekazano niemal $400 \mathrm{mln}$ PLN, mimo to wartość akcji poręczeniowej (z pomoca de minimis) nie przekroczyła $10 \mathrm{mln}$ PLN. Dopiero w IV kwartale, a więc po zmianie zasad udzielania pomocy de minimis, która została wprowadzona na podstawie Rozporzqdzenia Ministra Rozwoju Regionalnego z dnia 26 sierpnia 2010 roku zmieniajacego rozporzqdzenie w sprawie udzielania pomocy przez fundusze pożyczkowe i poreczeniowe w ramach regionalnych programów operacyjnych, wartość ta istotnie wzrosła. Ciekawym zjawiskiem jest również zasadniczy wzrost w IV kwartale 2010 roku zabezpieczeń wymaganych przez banki [Sytuacja na rynku kredytowym..., 2011, s. 3]. Może to być zarówno dodatkowy powód przyspieszenia akcji poręczeniowej, jak i skutek zmian prawnych w wyżej wymienionym rozporządzeniu określającym zasady udzielania pomocy de minimis, a tym samym większych oczekiwań banków na uruchomienie akcji poręczeniowej.

Kolejny, istotny wzrost akcji poręczeniowej odnotowano w II kwartale 2012 roku. Wynikał on z przyjęcia Rozporzqudzenia Wykonawczego Komisji (UE) Nr 1236/2011 zdnia 29 listopada 2011 roku zmieniajacego rozporzqdzenie (WE) nr 1828/2006 w odniesieniu do inwestycii z. wykoraystaniem instrumentów insynierii finansowej. Zmiana ta polegała na usunięciu $\mathrm{z}$ art. 45 Rozporzqdzenia Komisji (UE) 1828/2006 ograniczenia co do inwestowania: $w$ przedsiębiorstwa na etapie ich powstawania, wrzesnej driałalności, włacznie z kapitałem zalażkowym, lub prazy ich roz̧budowie. Następstwem przedmiotowej zmiany było przyjęcie 8 lutego 2012 roku dokumentu Revised Guidance Note on Financial Engineering Instruments under Article 44 of Council Regulation (EC) No. 1083/2006 (COCOF_10-0014-05-EN), który doprecyzowywał stosowanie przedmiotowych regulacji. 
Od I kwartału 2013 roku jest widoczny spadek akcji poręczeniowej, który miał kulminacyjny moment w III kwartale 2013 roku. Niewątpliwie, jest to związane z uruchomieniem w tym okresie rządowego programu gwarancji de minimis. Zgodnie z założeniami, gwarancje Banku Gospodarstwa Krajowego udzielane w formie pomocy publicznej lub pomocy de minimis mogą być dystrybuowane w ramach portfelowej linii gwarancyjnej (PLD) polegającej na: udzielaniu bankom gwarancïi portfela kredytowego, obejmujacego kredyty obrotowe dla mikroprzedsiębiorców, matych i średnich przedsiebiorców w ramach pomocy de minimis [Program..., 2013]. Jak widać, mimo ściśle ustalonej demarkacji między instrumentem BGK a instrumentami wdrażanymi w ramach funduszy europejskich, wdrożenie tego pierwszego spowodowało spadek akcji poręczeniowej (PLD, tak jak wspomniano wcześniej, miała poręczać wyłącznie kredyty obrotowe, których możliwość wykorzystania w ramach środków europejskich jest ograniczona).

Powyższe wnioski potwierdza również analiza wykresu 3., który pokazuje relację wielkości pomocy brutto do pomocy netto. Wyższa wartość wskaźnika oznacza wyższą korzyść osiąganą przez klienta otrzymującego gwarancję lub poręczenie ${ }^{3}$. Dla ułatwienia analizy dodano słupek błędów z odchyleniem standardowym.

\section{Wielkość pomocy brutto do pomocy netto}

WYKRES 3.

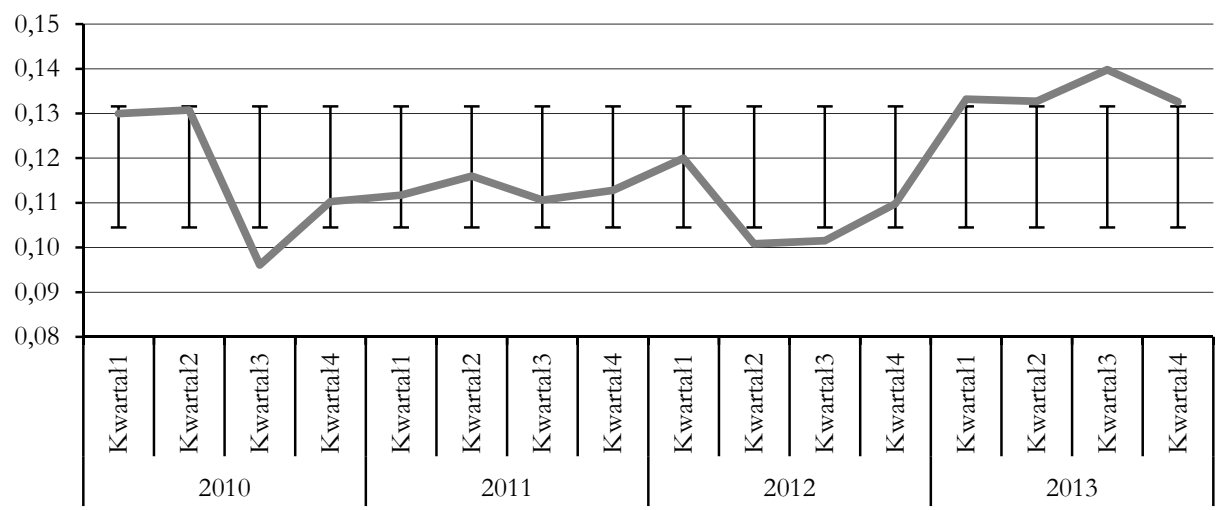

Źródło: opracowanie własne na podstawie danych UOKiK.

Pierwszym, opisywanym na wykresie 3. okresem jest III kwartał 2010 roku. Odnotowany w tym czasie spadek wskaźnika może sugerować zmniejszenie przez pośredników korzyści dla przedsiębiorców w związku z planowanym zwiększeniem popytu wynikającym ze zmiany Rozporzqdzenia Ministra Rozwoju Regionalnego z. dnia 26 sierpnia 2010 roku zmieniajacego rozporzqdzenie w sprawie udzielania pomocy przez fundusze po zyczkowe i poreczeniowe w ramach regionalnych programów operacyjnych. Jednak należy pamiętać, iż wartość akcji poręczeniowej w tym czasie była niewielka, co może wpływać na wyniki.

3 Analiza nie uwzględnia zmiany stopy referencyjnej. 
Kolejny okres to II i III kwartał 2012 roku, kiedy wartość wskaźnika przekroczyła odchylenie standardowe. W tym przypadku spadek wartości do 0,1 może wynikać analogicznie jak przy omawianiu wykresu 2. - ze zmiany art. 45 Rozporzqdzenia Komisji (UE) 1828/2006 i Noty COCOF. Oznacza to, iż zadziałały klasyczne mechanizmy rynkowe - zwiększenie popytu spowodowało spadek korzyści w celu utrzymania równowagi.

Ostatni okres to III kwartał 2013 roku, który na wykresie 2. odpowiada znaczącemu spadkowi akcji poręczeniowej spowodowanej wprowadzeniem rządowej gwarancji de minimis. W tym przypadku zwiększenie korzyści dla przedsiębiorców może wynikać z próby utrzymania akcji poręczeniowej przez pośredników.

\section{Źródło pochodzenia środków}

WYKRES 4.

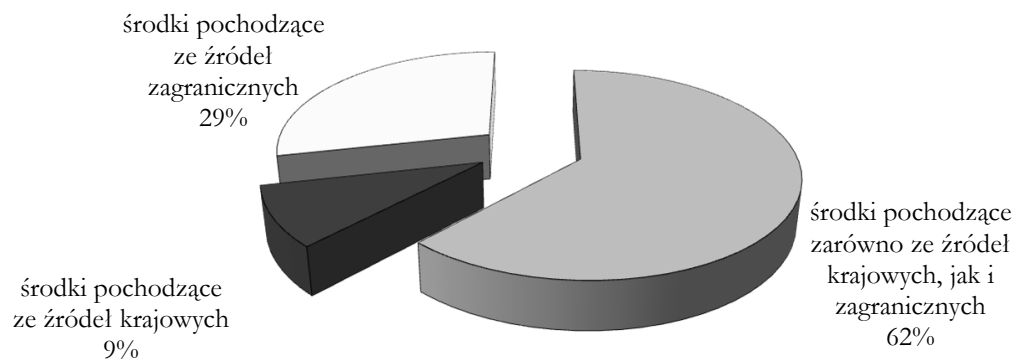

Źródło: opracowanie własne na podstawie danych UOKiK.

Analizując źródła finansowania gwarancji, których udzielono przedsiębiorcom na podstawie Ustany z dnia 6 grudnia 2006 roku o zasadach prowadzenia polityki rozwoju (Dz. U. 2006, Nr 227, poz. 1658) należy stwierdzić, iż przeważająca większość instrumentów jest zabezpieczona zarówno środkami krajowymi, jak i zagranicznymi. Pochodzenie środków krajowych jest tutaj trudne do rozstrzygnięcia, gdyż może to być w równej mierze wkład Budżetu Państwa do Regionalnych Programów Operacyjnych wypłacany na mocy kontraktów wojewódzkich, jak i wkład prywatny funduszy, które nie otrzymały dofinansowania na wszystkie wydatki kwalifikowalne. Operacje, w których występuje tylko pomoc zagraniczna, stanowią około $29 \%$ całej udzielonej pomocy publicznej, natomiast $9 \%$ obejmują operacje finansowane wyłącznie ze środków krajowych. W tym ostatnim przypadku operacje te są zapewne częścia portfela, w którym znajdują się również poręczenia finansowane ze środków zagranicznych. 


\section{Podsumowanie}

Zaprezentowane opracowanie dotyczy analizy poręczeń udzielanych w latach 2007-2013 i współfinansowanych ze środków europejskich. Do najważniejszych wniosków można zaliczyć dwa. Po pierwsze, system poręczeniowy w Polsce wydaje się mieć wąskie możliwości działania. Dowodem na poparcie tego wniosku jest skokowe przyspieszenie wdrażania instrumentów wsparcia jakości kredytowej, w wyniku wprowadzenia istotnych zmian regulacyjnych. W pierwszych trzech kwartałach działalności, kiedy było dopuszczalne wyłącznie inwestowanie w przedsiębiorstwa będące we wczesnej fazie działania - a więc w te przedsiębiorstwa, które ze względu na brak zabezpieczeń lub pozytywnej historii kredytowej mają największe problemy z dostępem do finansowania zewnętrznego - pośrednicy, którzy otrzymali już ponad $200 \mathrm{mln}$ PLN albo wcale nie rozpoczęli działalności operacyjnej, albo prowadzili ją w sposób mało skuteczny. Należy podkreślić, iż brak działalności operacyjnej mógł być następstwem trwającego dopiero przygotowywania do uruchomiania instrumentów. Niemniej o podejmowanych próbach może świadczyć wysoki wskaźnik korzyści dla przedsiębiorców, jaki obowiązywał w I i II kwartale 2010 roku.

Drugi wniosek wiąże się z ekonomiczną analizą prawa. Zakładając, iż publiczna interwencja za pośrednictwem instrumentów poręczeniowych przynosi korzyść netto gospodarce, można stwierdzić, iż bez względu na problemy pośredników błędne regulacje ograniczają maksymalizację korzyści płynących z wdrażania instrumentów zwrotnych. Niewykorzystanie tych korzyści oznacza więc stratę w rozumieniu Pareto.

W perspektywie finansowej 2014-2020 jest zatem konieczne jak najszybsze wdrożenie optymalnych regulacji zarówno na szczeblu krajowym, jak i unijnym. Brak takich regulacji może skutkować utrzymaniem się ograniczenia w dostępie do finansowania zewnętrznego mikro, małych i średnich przedsiębiorstw. Jednak nie zwalnia to pośredników finansowych z podejmowania aktywnych działań mających na celu rozszerzenie grupy odbiorców końcowych, tak aby działalność poręczeniowa mogła być zdywersyfikowana.

\section{Literatura}

Analiza Stanu Rynku Funduszy Poreczeń Kredytowych Polsce. Ocena i Perspektymy Rozwoju 2014, PAG Uniconsult, opracowanie przygotowane na zlecenie Związku Banków Polskich, Warszawa.

Dane Urzedu Ochrony Konkurencii i Konsumentów (UOKiK) nt. pomocy publicznej w latach 20072013 dla programu pomocowego SA.34331(2012/X), (zmiana X767/ 2009) oraz dla beneficjentów określonych w poz. C1 i D1 w Raporcie o pomocy de minimis w Polsce udrielonej przedsiebiorcom w 2012 roku [w posiadaniu autora].

Informacja BGK nt. wartość udizielonych poręzeń de minimis [w posiadaniu autora].

Informacja kwartalna nt. stanu realizacii instrumentów zwrotnych w ramach NSRO, MRR, stan na koniec II kwartał 2013 roku, informacja udostępniona przez Ministerstwo Infrastruktury i Rozwoju (dawniej Ministerstwo Rozwoju Regionalnego), [w posiadaniu autora]. 
Kodeks Cywilny - tekst jednolity, Dz. U. 2014, poz. 121.

Program: „W spieranie przedsiebiorczości z. uykeorzystaniem poreczeń i guvarancï Banku Gospodarstwa Krajowego", zm. z dnia 14 lutego 2013 roku, dokument elektroniczny, tryb dostępu: [http://www.mf.gov.pl/ministerstwo-finansow/dzialalnosc/poreczenia-i-gwarancje/ programy;jsessionid=E0E741D1F1C552F83C993759FBB34A7C, data wejścia: 20.07.2014].

Stan realizagi PO RPW 2007-2013, Komitet Monitorujący PO RPW 2007-2013, 11 czerwca 2014 rok, dokument elektroniczny, tryb dostępu: [http://www.polskawschodnia.gov.pl/OrganizacjaFunduszyEuropejskich/KompetencjeInst/posiedzeniaKM/ Documents/Stan_realizacji_PO\%20RPW_2007_2013.pdf, data wejścia: 23.07.2014]. Stan wdrażania Regionalnych Programón Operacyjnych 2007-2013 na dzৃien 31.01.2014, Wydział Sprawozdawczości i Monitoringu Rzeczowego Departamentu Koordynacji Wdrażania Programów Unii Europejskiej Ministerstwa Infrastruktury i Rozwoju (Instytucja Koordynująca NSRO) pod redakcja Aleksandra Dwornika i Joanny Kubickiej, 7 lutego 2014 rok, dokument elektroniczny, tryb dostępu: [http://www.funduszeeuropejskie.gov.pl/RPO/Aktualnosci/Documents/RPO_stan_wdrazania_310114.pdf, data wejścia: 23.07.2014]. 